\title{
Composite cement mortars based on marine sediments and oyster shell powder
}

\author{
H. Ez-zaki $\bowtie$, A. Diouri ${ }^{\text {a }}$, S. Kamali-Bernard ${ }^{\mathrm{b}}$, O. Sassi ${ }^{\mathrm{c}}$ \\ a. Faculté des Sciences Université Mohammed V, (Rabat, Maroc) \\ b. Institut National des Sciences Appliquées, Université Européenne de Bretagne, (Rennes Cedex, France) \\ c. Ecole Normale Supérieure, Université Mohammed V(Rabat, Maroc) \\ \ezzaki86@gmail.com
}

Received 26 February 2015

Accepted 11 September 2015

Available on line 04 february 2016

\begin{abstract}
Additions of dredged marine sediments and oyster shell powder (OS) as cement substitute materials in mortars are examined by several techniques. The sediments have high water and chloride contents and calcite, quartz, illite and kaolinite as principal minerals. The OS powders are entirely composed of calcium carbonate and traces of other impurities. Four mixtures of treated sediments and OS powders at $650{ }^{\circ} \mathrm{C}$ and $850{ }^{\circ} \mathrm{C}$ are added to Portland cement at $8 \%, 16 \%$ and $33 \%$ by weight. The hydration of composite pastes is followed by calorimetric tests, the porosity accessible to water, the bulk density, the permeability to gas, the compressive strength and the accelerated carbonation resistance are measured. In general, the increase of addition amounts reduced the performance of mortars. However, a reduction of gas permeability was observed when the addition was up to $33 \%$. Around $16 \%$ of addition, the compressive strength and carbonation resistance were improved.
\end{abstract}

KEYWORDS: Characterization; Hydration; Calorimetry; Mortar; Durability

Citation/Citar como: Ez-zaki, H.; Diouri, A.; Kamali-Bernard, S.; Sassi, O. (2016) Composite cement mortars based on marine sediments and oyster shell powder. Mater. Construcc. 66 [321], e080 http://dx.doi.org/10.3989/ mc.2016.01915.

RESUMEN: Morteros de cemento basado en sedimentos marinos y polvo de concha de ostra. En este trabajo se ha valorado la sustitución de cemento en morteros por sedimentos marinos dragados y polvo de concha de ostra (OS). Los sedimentos tienen altos contenidos de agua, cloruros, calcita, cuarzo, illita y caolinita como minerales principales. Los polvos OS están compuestos de carbonato cálcico y trazas de otras impurezas. Se añadieron a un cemento Portland, cuatro mezclas de los sedimentos y polvos de $\mathrm{OS}$ tratados a $650{ }^{\circ} \mathrm{C}$ y $850{ }^{\circ} \mathrm{C}$ en proporciones del $8 \%, 16 \%$ y $33 \%$ en peso. La hidratación de pastas se estudió a través de calorimetría. Se estudió además la porosidad accesible al agua, densidad aparente, permeabilidad al gas, resistencia a compresión y carbonatación acelerada. En general, un aumento en la adición produjo una reducción del rendimiento de los morteros. Se observó, sin embargo, una reducción de la permeabilidad a los gases con porcentajes de adición de hasta el 33\%. Con valores del 16\% de sustitución, mejoraron las resistencias mecánicas y la resistencia frente a la carbonatación.

PALABRAS CLAVE: Caracterización; Hidratación; Calorimetría; Mortero; Durabilidad

Copyright: (C) 2016 CSIC. This is an open-access article distributed under the terms of the Creative Commons Attribution-Non Commercial (by-nc) Spain 3.0 License. 


\section{INTRODUCTION}

With more than 10 billion tons of concrete that is produced globally each year, the cement industry has a large impact on the environment. Waste recycling has become a key issue in the science of building materials. Among these wastes, there are the dredged marine sediments that are available in large quantities. Their chemical compositions allows the use in this area, but their contamination requires pretreatment to remove organic pollutants (PAHs: polycyclic aromatic hydrocarbons, PCBs: polychlorinated biphenyls, TBT: tributyltin and dioxins) and stabilize inorganic pollutants (heavy metals like $\mathrm{Pb}$, $\mathrm{Cr}, \mathrm{Hg}, \mathrm{Zn}$ and $\mathrm{Cu})(1-3)$.

Researches show the feasibility of treated sediments as aggregates substitution in construction materials such as clay bricks (4), roads (5) and mortars $(3,6)$, Agostini et al. (3) found that the substitution of sand by sediments in the treated mortar increases immensely the porosity with the sediment content, while the bulk density decreases linearly with increasing porosity. Replacing up to $33 \%$ of the sand by treated sediments improves the Young's modulus, the compressive strengths and the apparent gas permeability compared to normal mortars (6). Aouad G. et al. (7) have observed that a replacement of a portion of $39 \%$ of cement clinker by the sediment after a special treatment may develop more compressive strengths.

The oyster shells are another marine waste that can be valorized in the construction sector. It is noted that the oyster shell powders (OS) consist entirely of calcium carbonate with few impurities $(8,9)$. When these powders are introduced in the concrete, workability decreases with the degree of substitution. It is found that the addition of OS powders does not cause a decrease in the compressive strength of concrete at the age of 28 days (10). Yoon GL. et al. (8) have shown that there is no significant reduction of the compressive strength when they replace up to $40 \%$ of sand by OS powder. Moreover, it is observed that the addition of moderate amounts of fly ash and OS powder as sand substituent in mortars improve workability, porosity, compressive strength and durability and reduce the absorption rate of mortars (9). The partial replacement of sand by OS powders in concrete has a positive effect on the resistance to freeze-thaw, drying shrinkage and water permeability. However, the OS powders have no negative effect on the chemical attack and carbonation of concrete. Other researchers have shown that these properties are significantly affected at relatively high degree of substitution, particularly for long-term performance (11).

The purpose of this study is to evaluate experimentally the possibility of replacing a portion of Portland cement CEM I 52.5 with an addition of heat-treated sediment and OS powders. A quantitative evaluation of the effect of substitution on the physical and mechanical proprieties and durability of mortars is achieved. Two different sediments are selected; sediment noted "L" from the trap Lyvet on the Rance river and sediment "M" from the bay of Mont Saint Michel (MSM) which both are in the west of France.

\section{MATERIALS AND TECHNIQUES}

\subsection{Analysis of raw materials}

The water content of the studied sediments was determined by drying three samples at $60^{\circ} \mathrm{C}$ until constant mass. The solid content was estimated to $42 \%$ for the sediment $M$, and $66 \%$ for the sediment $L$. A value of $0.80 \%$ was determined for the OS powder. To measure salinity of studied sediments, ion meters Consort C835, with two specific electrodes were used. Such materials were first heated at $105{ }^{\circ} \mathrm{C}$ to remove water and then suspended in deionized water at a $10: 1 \mathrm{l} / \mathrm{kg}$ liquid to solid ratio. The chloride content was found to be equal to $2.84 \mathrm{~g} / \mathrm{l}$ for the sediment L, $2.14 \mathrm{~g} / \mathrm{l}$ for the sediment $\mathrm{M}$ and $0.8 \mathrm{~g} / \mathrm{l}$ for the OS powder.

The particle size distribution test was performed using laser diffraction machine Cilas 1180. The samples were dispersed in the sodium hexametaphosphate solution. Some of the samples were treated with $\mathrm{H}_{2} \mathrm{O}_{2}$ to remove organic matter traces and to compare the size with or without organic matter $(\mathrm{OM})$. The median size of samples $\mathrm{M}$ and $\mathrm{L}$ with (OM) was found, respectively, equal to $46,1 \mu \mathrm{m}$ and $25.1 \mu \mathrm{m}$. After removal of the $(\mathrm{OM})$, the median size of $\mathrm{M}$ and $\mathrm{L}$ were equal to $29.3 \mu \mathrm{m}$ and $16.6 \mu \mathrm{m}$ respectively. The particle size of the OS powder with or without $(\mathrm{OM})$ is almost adjacent to $82 \mu \mathrm{m}$. It seemed that the organic matter plays a role of glue which assembles the fine grains of the sediments. The disappearance of the (OM) releases the smaller grains.

The concentrations of the major elements in the raw materials were analyzed by X-ray fluorescence and their chemical compositions are shown in Table 1. The major components are silicon, calcium, iron and aluminum. The sediment $\mathrm{L}$ contains more silicon and aluminum as the sediment $\mathrm{M}$. In contrast, the calcium content of the sediment $\mathrm{M}$ is twice as large as that of the sediment $\mathrm{L}$.

Chemical analysis of the OS powder shows major presence of calcium with traces of magnesium, sodium and phosphorus. The mineralogical characterization was carried out using a machine PHILIPS 3710 which operates at $30 \mathrm{kV}$ and $20 \mathrm{~mA}$ with a $\mathrm{Cu}$ anode. The diffractograms show the presence of quartz, calcite, illite and kaolinite in sediments and calcite in OS powder. 
TABLE 1. Chemical composition of raw materials

\begin{tabular}{lccc}
\hline Oxide (\%Wt) & Sediment $\mathbf{M}$ & Sediment $\mathbf{L}$ & OS \\
\hline $\mathrm{SiO}_{2}$ & 34.62 & 40.43 & - \\
$\mathrm{CaO}$ & 20.28 & 9.39 & 48 \\
$\mathrm{Fe}_{2} \mathrm{O}_{3}$ & 1.63 & 4.49 & - \\
$\mathrm{Al}_{2} \mathrm{O}_{3}$ & 1.79 & 5.27 & - \\
$\mathrm{Na}_{2} \mathrm{O}$ & 0.82 & 1.45 & 0.3 \\
$\mathrm{MgO}$ & 1.53 & 1.6 & 0.5 \\
$\mathrm{~K}_{2} \mathrm{O}$ & 0.37 & 0.76 & - \\
$\mathrm{SO}_{3}$ & 0.64 & 0.8 & - \\
$\mathrm{TiO}_{2}$ & 0.05 & 0.1 & - \\
$\mathrm{MnO}$ & 0.03 & 0.04 & - \\
$\mathrm{P}_{2} \mathrm{O}_{5}$ & - & - & 0.01 \\
Loss on ignition (\%) & 38 & 35 & 51 \\
\hline
\end{tabular}

\subsection{Treatment and characterization}

The high salinity of marine sediments implies a negative effect on the development of cement-based materials strength (5). To reduce the chloride content of studied sediments, a washing process used by Dang et al. (13) was made. It consists to dilute the sediment with water at 3:1 sediment to water ratio. Then the addition was decanted with a settling tank that allows the flow of the washing water. Measuring the amount of free chloride was performed on the final products. The analysis gave a residual value of about $0.43 \mathrm{~g} / \mathrm{l}$ and $0.58 \mathrm{~g} / \mathrm{l}$ against $2.14 \mathrm{~g} / \mathrm{l}$ and
$2.84 \mathrm{~g} / \mathrm{l}$ respectively of the $\mathrm{M}$ and $\mathrm{L}$ sediments. This result shows that used washing process decreases significantly, the chloride content in the raw sediment. After several days of setting, the sediments are dried in an oven at $40{ }^{\circ} \mathrm{C}$ until obtaining constant mass. The product is then crushed and sieved using a 200 micron sieve.

In order to remove all organic compounds and activate clay minerals, the materials are treated at high temperature. In our study, we followed the same temperatures used by Dang et al. $(12,13)$. His choice of the calcination temperature is based on the information provided by the thermal analysis. Two calcination temperatures are chosen for this study: $650^{\circ} \mathrm{C}$ is a temperature that allows the conversion of kaolin to metakaolin without degradation of calcium carbonate (13), and $850^{\circ} \mathrm{C}$ is a temperature that allows the decomposition of calcium carbonate. The calcination process consists in an increase of the ambient temperature to the selected temperature and then maintained constant for 5 hours to ensure the maximum transformation of the phases. Finally, the furnace is stopped for a natural cooling to room temperature. After the heat treatment, the visual examination shows a clear difference colors between the materials which indicate some differences in the composition. The treated powders are very fine. The particle size distribution was measured with the same method as described above. Six samples named: OS650, OS850, M650, M850, L650 and L850 were tested. The numbers after the letters indicate the treatment temperature. The results are shown in Figure 1.

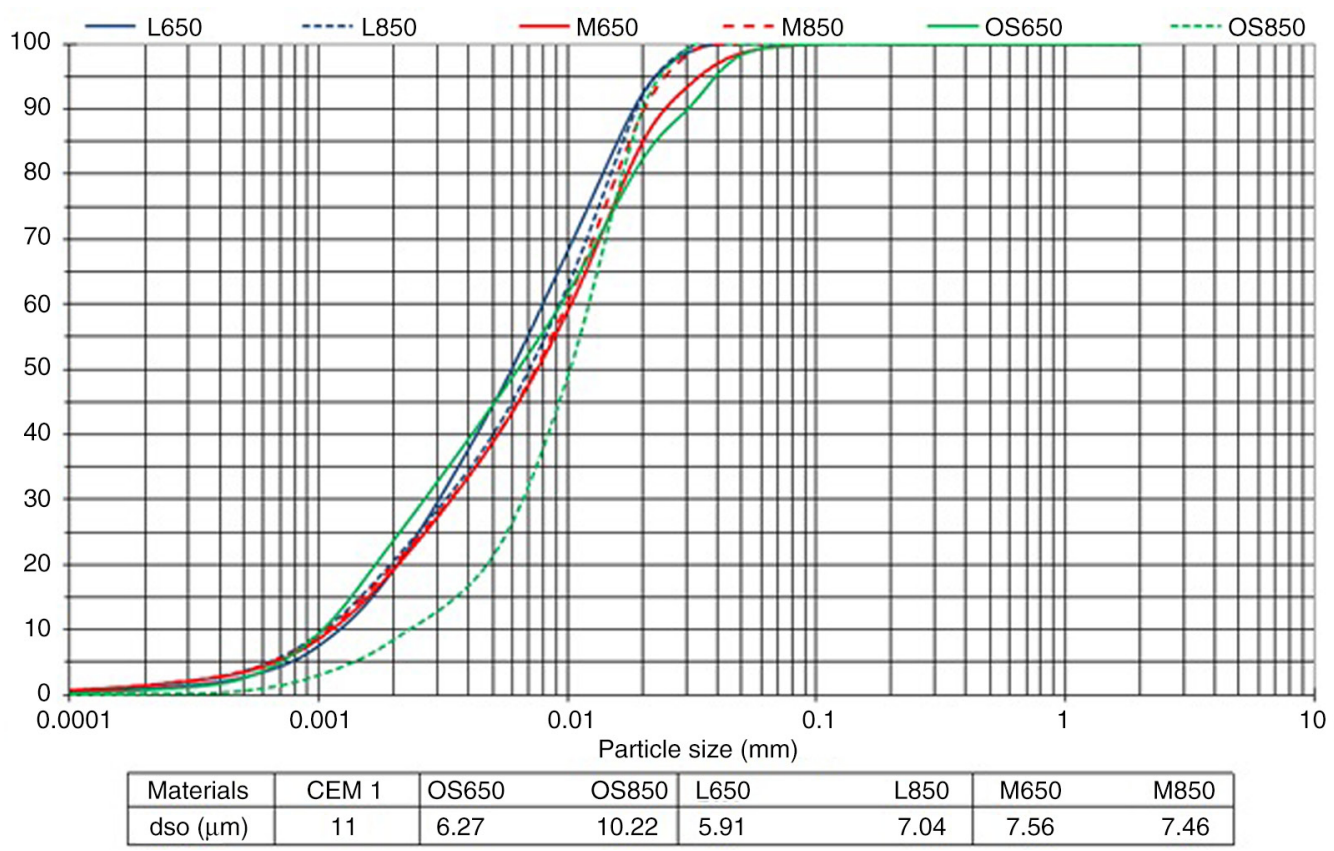

Figure 1. Particle size distribution of treated materials. 


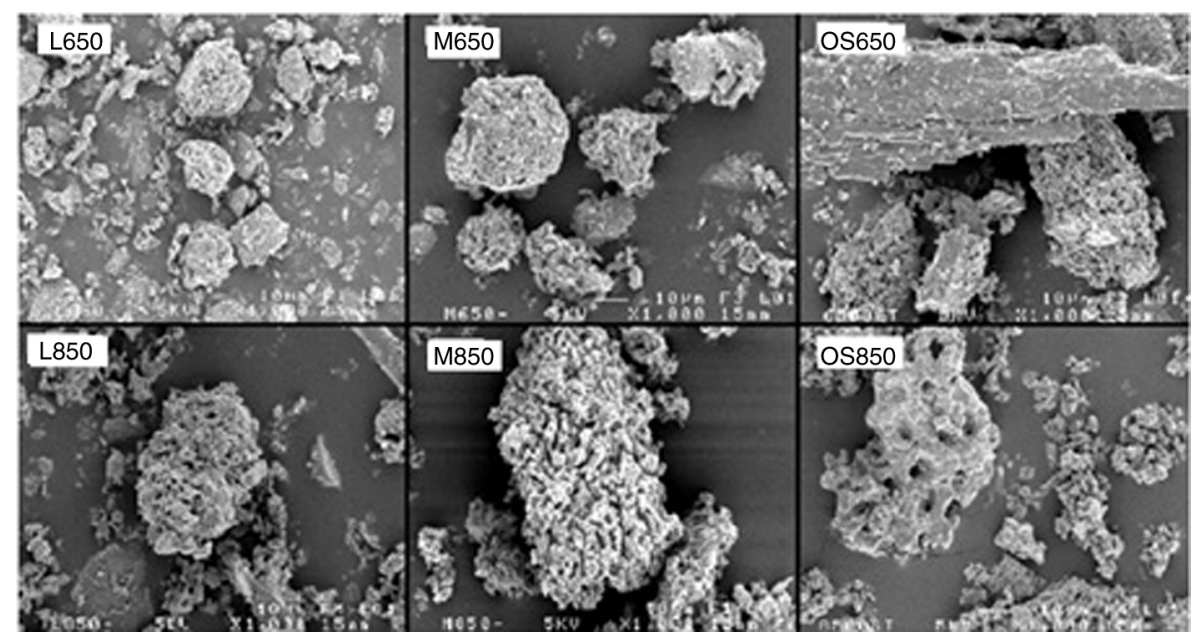

Figure 2. Morphology of the treated materials observed by SEM.

The morphology of the grains was obtained using JEOL JSM 6301F instrument. Figure 2 shows that the grains of all treated materials have the form of pellet except OS650 which have a needle forms and other coarse representing some forms of calcite. We note that on the surface of grains of treated sediments, there are recrystallized particles. This is the result of local melting during calcination. The treated sediments at $650{ }^{\circ} \mathrm{C}$ have a lot of fine particles furthermore the pellets. In contrast, the treated sediments at $850{ }^{\circ} \mathrm{C}$ have fewer fine particles. This can be explaining by the fact that they were melted during calcination and then they were cooled and recrystallized on the surface of grains.

The X-ray diffraction is used to define the entrained phase changes during the heat treatment of the sediments and OS powders. Diffractograms (Figures 3, 4 and 5) are obtained with the same machine.

On the diffractograms we identify quartz, calcite and illite in calcined sediment at $650^{\circ} \mathrm{C}$ and quartz and gismondine in calcined sediment at $850^{\circ} \mathrm{C}$. Kaolinite is absent in the treated sediment, it is converted to

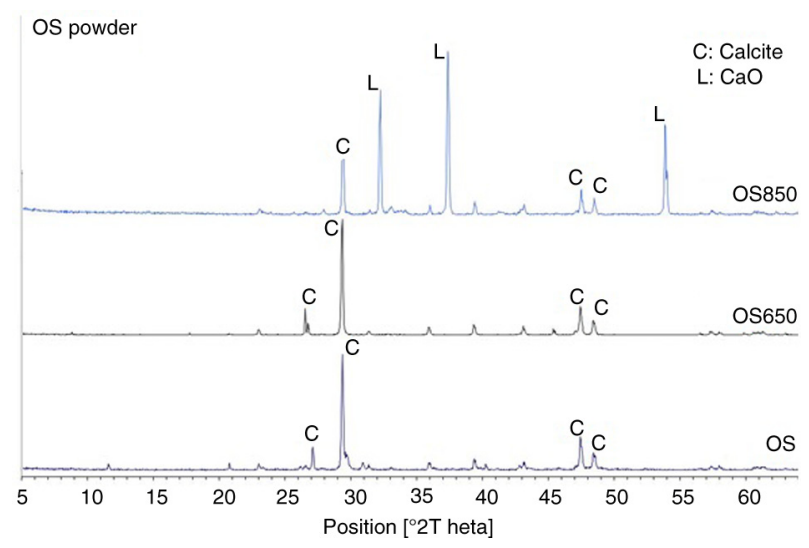

FIGURE 3. Diffraction diagram of treated OS powder. metakaolin, an amorphous phase, during the calcination at $650{ }^{\circ} \mathrm{C}$. Calcination of sediment at $850{ }^{\circ} \mathrm{C}$ has caused the decomposition of calcite and the formation of gismondine. It is known that quartz is resistant to high temperature. At $6500^{\circ} \mathrm{C}$, the OS powder diffraction pattern shows a major presence of calcite and the appearance of $\mathrm{CaO}$ at $850{ }^{\circ} \mathrm{C}$.

\subsection{Formulation of additions}

In this paper, we propose new composite cements based on additions of sediments and OS powder that are heat-treated. They are based on the goal of fixing a large amount of OS powder that represents the calcium carbonate (about 2/3) and varying the proportion of the two sediments namely the rest (about $1 / 3$ ) of single sediment or an addition of the two. Table 2 shows the composition of the three prepared substitution additions.

Four additions (OLM850; OLM650; OL650 and OM650) are prepared to replace $8 \%, 16 \%$ and 33\% by weight of Portland cement CEM I 52.5. These additions are then used to prepare pastes at waterto-binder ratio w/b equal to 0.4 and mortars at $\mathrm{w} / \mathrm{b}=0.5$. The proportions of appointed pastes and mortars are shown in Table 3.

The addition pastes are prepared in cylindrical molds (diameter $3.5 \mathrm{~cm} \times$ height $7 \mathrm{~cm}$ ). After poured in the molds, all specimens are placed in a moist chamber $(\mathrm{RH}>94 \%)$ at an average temperature of $20 \pm 2{ }^{\circ} \mathrm{C}$. The specimens were removed from the molds after 24 hours and then cured in water at $20 \pm 2{ }^{\circ} \mathrm{C}$ for 28 days. Mortars are prepared in accordance with EN 196-1 (14). Cylindrical $(4 \mathrm{~cm}$ diameter $\times 6 \mathrm{~cm}$ height $)$ and prismatic $(4 \times 4 \times 16 \mathrm{~cm})$ samples are performed.

In total, thirteen cylindrical samples of pastes are used for accelerated carbonation tests, twentysix cylindrical specimens of mortars for measuring 


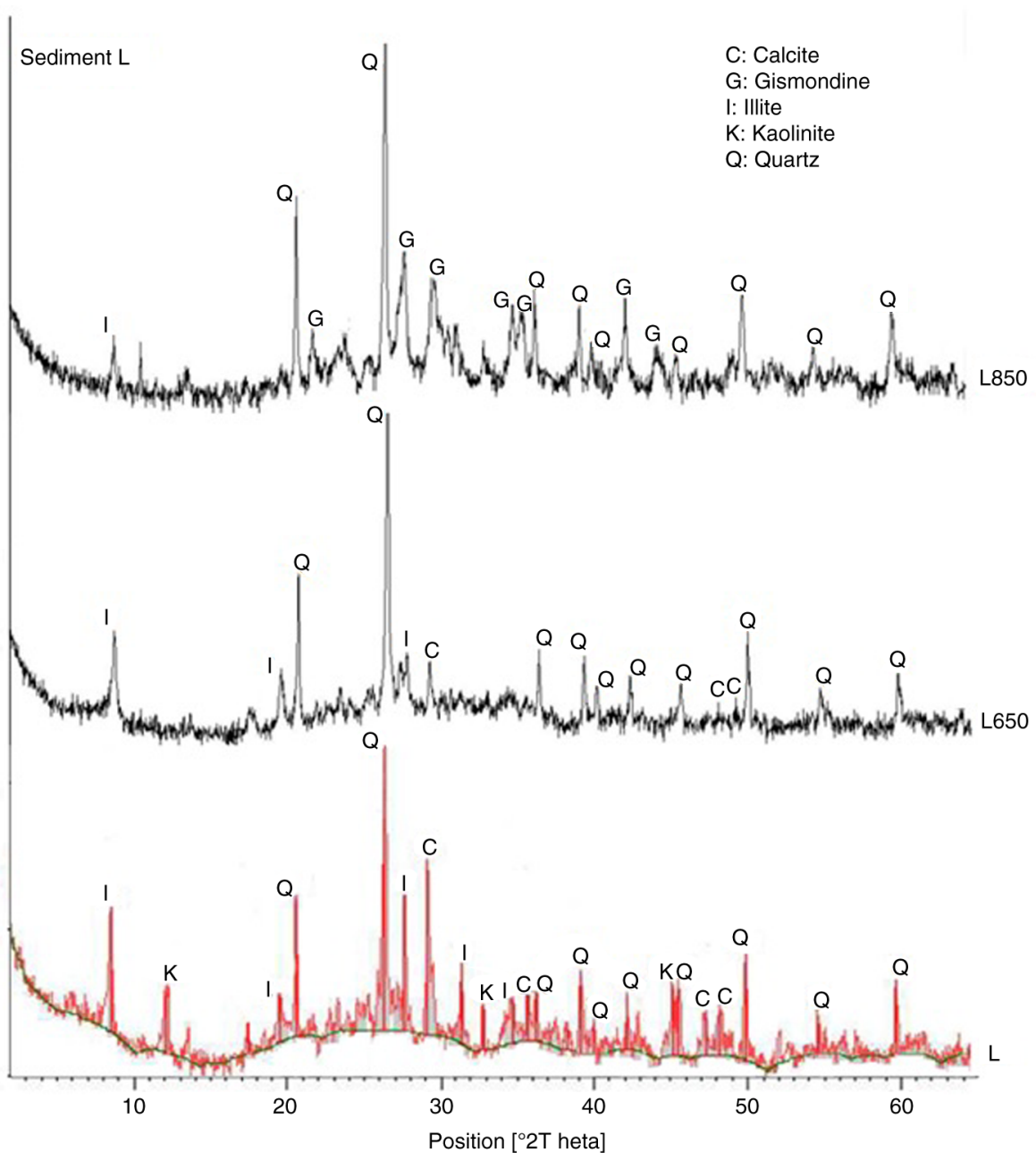

Figure 4. Diffraction diagram of treated Lyvet sediment.

the density, the porosity accessible to water and apparent gas permeability and thirty-nine prismatic mortars for the compressive strength tests. The designation of the samples is as follows: the number after the first letter refers to the substitution rate of cement by the addition; the number is followed by the name of the addition. For example, the specimen R8OL650 refers to a mortar with $8 \%$ by weight of the binder OL650.

\subsection{Characterization techniques}

The evolution of the heat of hydration was followed using a Tian-Calvet microcalorimeter. The sample is weighed and uniformly distributed in the sample container. Water is measured and introduced via a syringe. The mass of the binder used is $0.5 \mathrm{~g}$ and water/solid ratio is equal to 0.5 . The measurement of the heat evolution was performed at a constant temperature of $23 \pm 1{ }^{\circ} \mathrm{C}$. The released hydration heat was saved as voltage and then converted to $\mathrm{mW} / \mathrm{g}$ with a constant derived from a calibration test.
Various tests were made: the bulk density, the porosity accessible to water, the apparent permeability and the accelerated carbonation were all performed on the cylindrical mortar, the mechanical strength were performed on the prismatic mortars. Density $\left(D_{a}\right)$ and porosity $\left(P_{a}\right)$ were measured and calculated according to the recommendation of AFREM (15). The mass of each test piece was measured in the air and under water with a hydrostatic balance. After, they are dried in a ventilated oven at $105^{\circ} \mathrm{C}$ until stabilization of the mass (after 2 days). This procedure is very fast, but it modifies the pores structure and can cause some microscopic cracks due to the drying and it increases the gas permeability $(16,17)$. The apparent gas permeability $\left(\mathrm{K}_{\mathrm{a}}\right)$ was measured by applying a constant pressure $\left(\mathrm{P}_{1}=0.3 \mathrm{MPa}\right)$ of the Helium gas between the two extremities of the dried specimens and measured the resulting flow. The measured value was calculated by applying Darcy's law [1]:

$$
K_{\alpha}=\frac{Q_{2}}{S} 2 \cdot \mu \cdot L \cdot \frac{P_{2}}{\left(P_{1}^{2}-P_{2}^{2}\right)}
$$




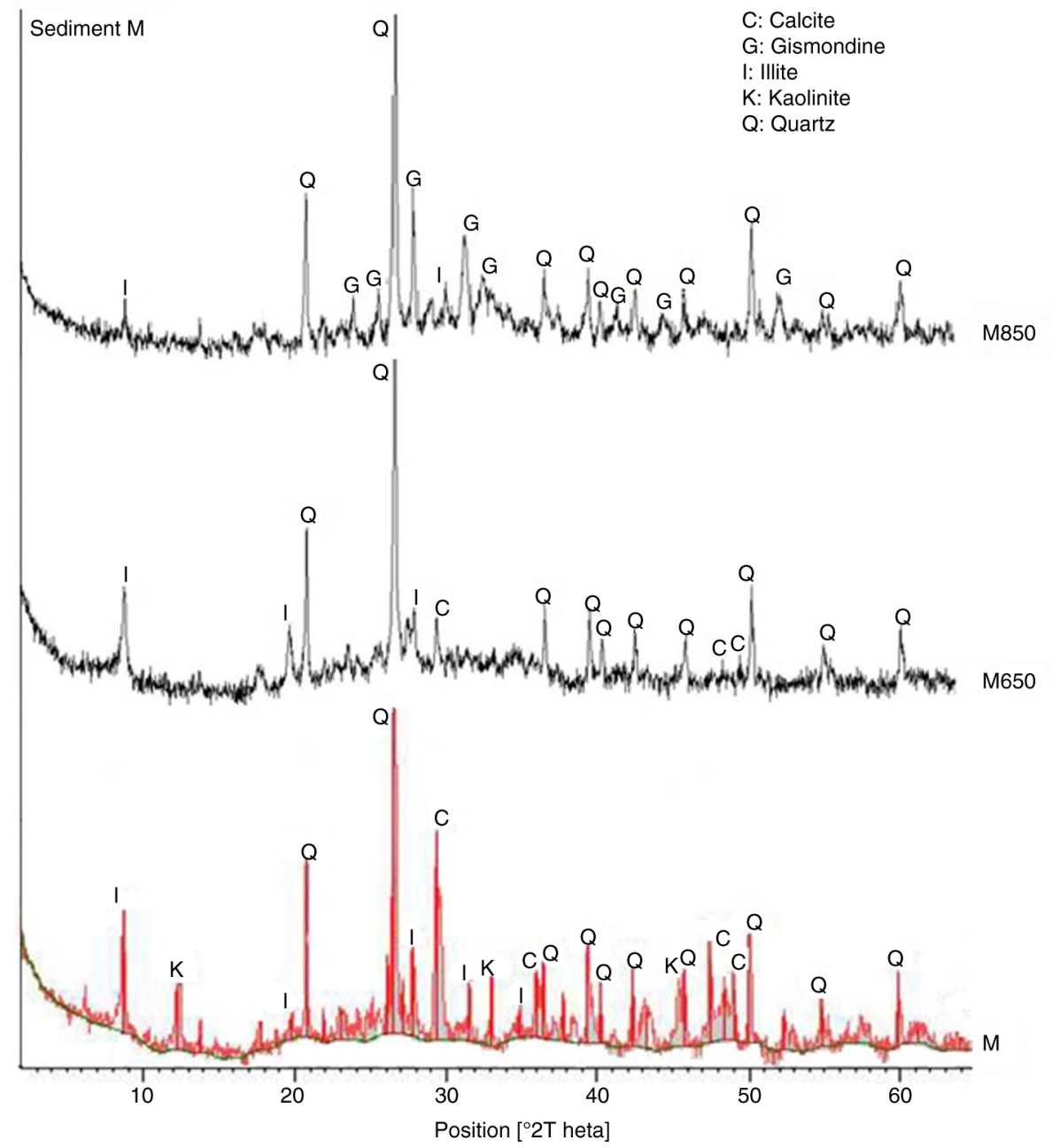

FIGURE 5. Diffraction diagram of treated MSM sediment.

$\mathrm{K}_{\mathrm{a}_{2}}$ is the apparent gas permeability of the sample $\left(\mathrm{m}^{2}\right)$; $\mathrm{L}$ the length of the sample $(\mathrm{m}) ; \mathrm{Q}_{2}$ the measured gas flow $\left(\mathrm{m}^{3} / \mathrm{s}\right) ; \mathrm{S}$ the cross section area $\left(\mathrm{m}^{2}\right) ; \mu$ the viscosity coefficient of the gas (Pa.s); $\mathrm{P}_{1}$ the applied absolute pressure $(\mathrm{Pa})$ and $\mathrm{P}_{2}$ the atmospheric pressure $(\mathrm{Pa})$. For each value, two specimens are used and the average value is taken in to account.

The mechanical strengths were obtained on prismatic samples with the INSTRON ${ }^{\circledR}$ machine. The samples are first cut into two parts by using the flexion test. Then the compression test is performed on each of the two parts. Six values of compressive strength are obtained, the averages are listed.

TABLE 2. Proportions of substitution additions

\begin{tabular}{lccc}
\hline Additions & OS & L & M \\
\hline OLM & $2 / 3$ & $1 / 6$ & $1 / 6$ \\
OL & $2 / 3$ & $1 / 3$ & - \\
OM & $2 / 3$ & - & $1 / 3$ \\
\hline
\end{tabular}

The cylindrical pastes are cut into two symmetrical parts and covered with adhesive aluminum foil on both surfaces to allow an unidirectional carbonation. Then they were maintained in a climate cell at $35^{\circ} \mathrm{C}, 70 \%$ of relative humidity and $20 \%$ of $\mathrm{CO}_{2}$ in volume.

\section{RESULTS AND DISCUSSIONS}

\subsection{Hydration behavior}

It is generally accepted that the early hydration of Portland cement can be divided into five periods on the basis of the evolution of heat curves (18). (I): The initial period (pre-induction) is the first peak which appeared in the first minutes produced by the dissolution of the cement. (II): The induction period between the first and the second peak corresponds to the saturation of the mixing water by soluble ions. The setting starts when the ion concentration is critical. This saturation induces the precipitation 
TAble 3. Composition of studied pastes (C) and mortars (R). Cyl.: Cylindric , Pris.: Prismatic

\begin{tabular}{|c|c|c|c|c|c|c|c|c|c|c|c|c|c|c|}
\hline Paste & \multicolumn{2}{|c|}{ CEM I (g) } & \multicolumn{2}{|c|}{ OLM850 (g) } & \multicolumn{2}{|c|}{ OLM650 (g) } & \multicolumn{2}{|c|}{ OL650 (g) } & \multicolumn{4}{|c|}{$\begin{array}{l}\text { Normalised } \\
\text { sand (g) }\end{array}$} & \multicolumn{2}{|c|}{ Water (g) } \\
\hline $\mathrm{C}$ & \multicolumn{2}{|c|}{210} & \multicolumn{2}{|c|}{-} & \multicolumn{2}{|c|}{-} & \multicolumn{2}{|c|}{-} & \multicolumn{2}{|c|}{-} & \multicolumn{2}{|c|}{-} & \multicolumn{2}{|c|}{84} \\
\hline C8OLM850 & \multicolumn{2}{|c|}{193.2} & \multicolumn{2}{|c|}{16.8} & \multicolumn{2}{|c|}{-} & \multicolumn{2}{|c|}{ - } & \multicolumn{2}{|c|}{ - } & \multicolumn{2}{|c|}{ - } & \multicolumn{2}{|c|}{84} \\
\hline C16OLM850 & \multicolumn{2}{|c|}{176.4} & \multicolumn{2}{|c|}{33.6} & \multicolumn{2}{|c|}{-} & \multicolumn{2}{|c|}{ - } & \multicolumn{2}{|c|}{ - } & \multicolumn{2}{|c|}{ - } & \multicolumn{2}{|c|}{84} \\
\hline C33OLM850 & \multicolumn{2}{|c|}{140.7} & & & & & & & & & & & 8 & \\
\hline C8OLM650 & & 3.2 & & & & & & & & & & & 8 & \\
\hline C16OLM650 & & 6.4 & & & & & & - & & & & - & 8 & 4 \\
\hline C33OLM650 & & 0.7 & & & & & & & & & & & 8 & \\
\hline C8OL650 & & 3.2 & & & & & & 8 & & & & & 8 & 4 \\
\hline C16OL650 & & 6.4 & & & & & & 6 & & & & - & 8 & 4 \\
\hline C33OL650 & & 0.7 & & & & & & .3 & & & & & 8 & 4 \\
\hline C8OM650 & & 3.2 & & & & & & & & & & & 8 & 4 \\
\hline C16OM650 & & 6.4 & & & & & & & & & & & 8 & 4 \\
\hline C33OM650 & & 0.7 & & & & & & & & & & & & 4 \\
\hline Mortar & Cyl. & Pris. & Cyl. & Pris. & Cyl. & Pris. & Cyl. & Pris. & Cyl. & Pris. & Cyl. & Pris. & Cyl. & Pris. \\
\hline $\mathrm{R}$ & 225 & 450 & - & - & - & - & - & - & - & - & 675 & 1350 & 112.5 & 225 \\
\hline R8OLM850 & 207 & 414 & 18 & 36 & - & - & - & - & - & - & 675 & 1350 & 112.5 & 225 \\
\hline R16OLM850 & 189 & 378 & 36 & 72 & - & - & - & - & - & - & 675 & 1350 & 112.5 & 225 \\
\hline R33OLM850 & 150 & 300 & 75 & 150 & - & - & - & - & - & - & 675 & 1350 & 112.5 & 225 \\
\hline R8OLM650 & 207 & 414 & - & - & 18 & 36 & - & - & - & - & 675 & 1350 & 112.5 & 225 \\
\hline R16OLM650 & 189 & 378 & - & - & 36 & 72 & - & - & - & - & 675 & 1350 & 112.5 & 225 \\
\hline R33OLM650 & 150 & 300 & - & - & 75 & 150 & - & - & - & - & 675 & 1350 & 112.5 & 225 \\
\hline R8OL650 & 207 & 414 & - & - & - & - & 18 & 36 & - & - & 675 & 1350 & 112.5 & 225 \\
\hline R16OL650 & 189 & 378 & - & - & - & - & 36 & 72 & - & - & 675 & 1350 & 112.5 & 225 \\
\hline R33OL650 & 150 & 300 & - & - & - & - & 75 & 150 & - & - & 675 & 1350 & 112.5 & 225 \\
\hline R8OM650 & 207 & 414 & - & - & - & - & - & - & 18 & 36 & 675 & 1350 & 112.5 & 225 \\
\hline R16OM650 & 189 & 378 & - & - & - & - & - & - & 36 & 72 & 675 & 1350 & 112.5 & 225 \\
\hline R33OM650 & 150 & 300 & - & - & - & - & - & - & 75 & 150 & 675 & 1350 & 112.5 & 225 \\
\hline
\end{tabular}

of Portlandite $\mathrm{Ca}(\mathrm{OH})_{2}$ and $\mathrm{CSH}$ gel which releases an evolution of heat which is noted the acceleration period (III). The deceleration period (IV) starts at the top of the second peak corresponds to the hardening onset which slows the hydration reactions. The diffusion period $(\mathrm{V})$ is the end of the rate of heat. The test results of isothermal heat evolution rate $(\mathrm{mW} / \mathrm{g})$ of all studied samples are shown in Figure 6.

In all the figures (a), (b), (c) and (d) we represent the hydration curve of the reference sample, the cement CEM I which is noted by the letter C. We observe, for this sample, the normal behavior of this type of cement which shows the appearance of a first initial peak $(1.65 \mathrm{~mW} / \mathrm{g})$ immediately after the addition of water, it is attributed to the dissolution of alkalis and the formation of ettringite (AFt) (18). At the end of the induction period, the solution becomes super saturated with $\mathrm{Ca}^{2+}$ and $\mathrm{OH}^{-}$and the $\mathrm{Ca}(\mathrm{OH})_{2}$ phase began its nucleation. After this induction period was ended, the second peak corresponded to the acceleration of the $\mathrm{C}_{3} \mathrm{~S}$ hydration and initial precipitation of $\mathrm{CSH}$ gel and Portlandite reaction $(19,20)$. The second peak reaches a heat rate of $5.34 \mathrm{~mW} / \mathrm{g}$ after approximately 9 hours. Lagier et al. (18) have found that the second peak of different Portland cements generally occurred between 8.5 and 9.5 hours. After this time, the hydration reaction is slower but continuous and the heat rate is lower.

It is known in the literature on hydration of Portland clinkers that the calorimetric curves may present an additional peak when the amounts of aluminates are excessive $(18,21,22)$. The calorimetric curves exhibit three peaks for blended samples with high amount of $\mathrm{C}_{3} \mathrm{~A}$ corresponding respectively one to the initial hydrolysis, second to hydration of $\mathrm{C}_{3} \mathrm{~S}$ and third to the transformation of etttringite AFt to monosulfoaluminate AFm phase due to the presence of a large quantity of $\mathrm{C}_{3} \mathrm{~A}$. The calorimetric curve of samples with weak quantity of $\mathrm{C}_{3} \mathrm{~A}$ shows only two peaks corresponding to initial hydrolysis and $\mathrm{C}_{3} \mathrm{~S}$ hydration. 

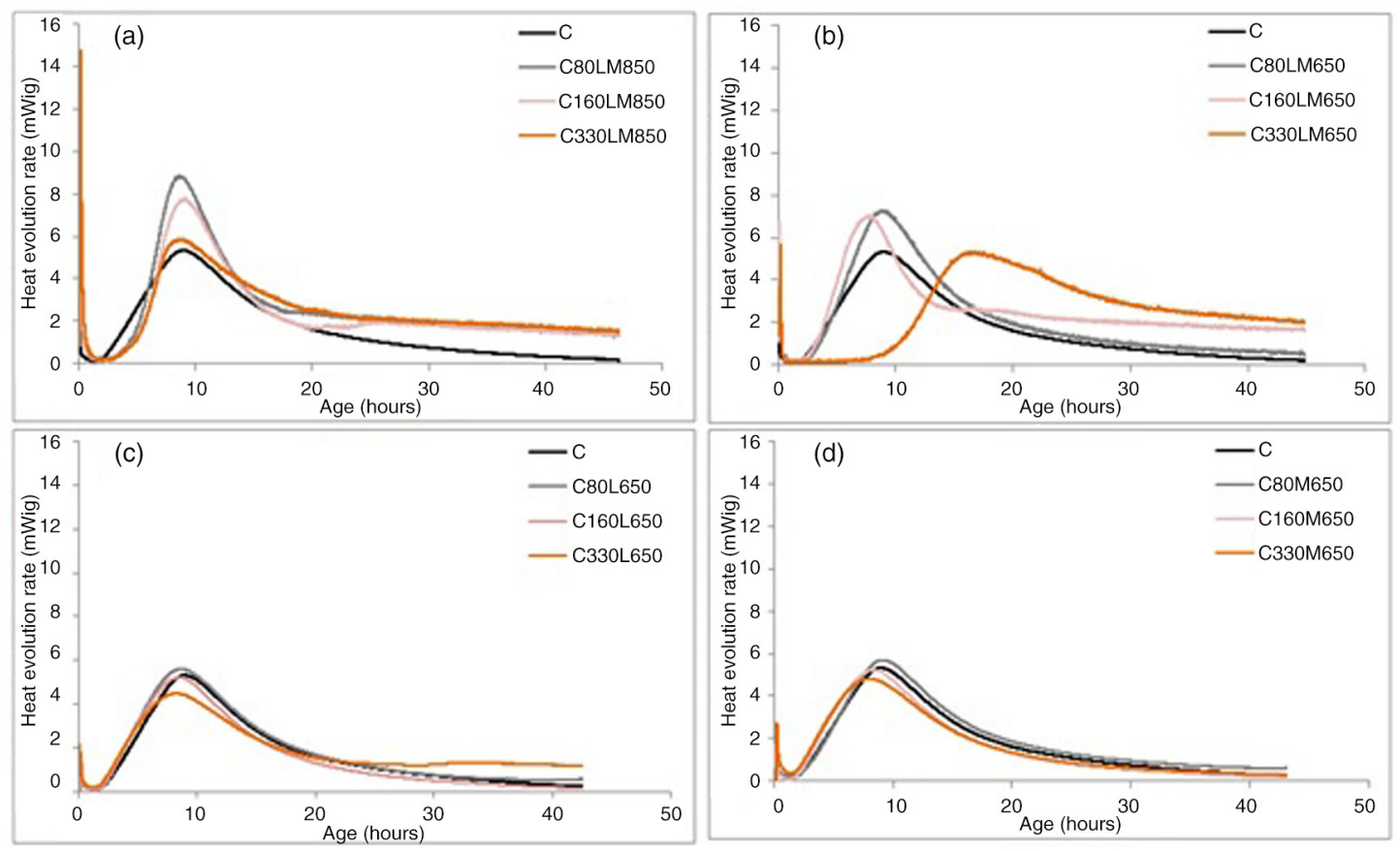

FIGURE 6. Isothermal hydration curves of cementitious mixtures COLM850 (a), COLM650 (b), COL650 (c) and COM650 (d).

In blends where some part of the cement is replaced by additions of shell powders mixed with only one sediment (samples with COL or COM additions, Figure $6 \mathrm{c}$ or $6 \mathrm{~d}$ ), the calorimetric heat evolution is similar to that of CEM I cement. But an important hydration heats are noted for all samples containing the additions of two sediments L and M (samples with COLM addition in curves of Figures $6 a$ and $6 b$ ).

During the first stage, the first peak amplitude becomes larger than of the ordinary paste. The values of 8.91 and $4.94 \mathrm{~mW} / \mathrm{g}$ are obtained when we introduce $8 \%$ of OLM850 and OLM650 binders respectively. The amplitude of this first peak increases also with the proportion of the addition.

After the induction period, usually the second peak occurs between 8 and 9 hours in all samples except for C33OLM650 with 33\% of OLM binder treated at $650{ }^{\circ} \mathrm{C}$, the second peak was delayed until 17 hours. For this sample, a long induction period of about 10 hours was observed.

For samples containing LM sediment additions, the highest second peak is noted for the sample with $8 \%$ of OLM850. It is clearly observed that the increase of the addition amount decreases the heat rate, but still higher than that of ordinary paste C, these values decrease from 8.91 to $5.95 \mathrm{~mW} / \mathrm{g}$ for $8 \%$ to $33 \%$ in OLM 850 binder respectively and from 7.38 to $5.39 \mathrm{~mW} / \mathrm{g}$ for $8 \%$ to $33 \%$ in OLM650 binder, while this value does not exceed $5.34 \mathrm{~mW} / \mathrm{g}$ for the reference paste $\mathrm{C}$.

After the second peak, a weak heat generation during the deceleration period was observed for all samples containing LM additions, the measured heat rates were 2.52, 2.19, 2.64, 2.70 and $4.23 \mathrm{~mW} / \mathrm{g}$ for samples C8OLM850, C16OLM850, C33OLM850, C16OLM650 and C33OLM650 respectively at $19 \mathrm{~h}$

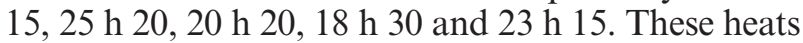
can be attributed to the third peak which corresponds to the conversion reaction of ettringite ( $\mathrm{AFt}$ ) to monosulfate (AFm) in the presence of high quantities of aluminates and metakaolin from the sediment L (18).

For the samples containing single sediment in COL650 and COM650 additions, it was observed a decrease of the heat rates with the increase of the addition rates. The maximum values of heat rates of 5.63 and $5.70 \mathrm{~mW} / \mathrm{g}$ were observed for the addition of $8 \%$ in C8OL650 and C8OM650 respectively.

We have studied (23) the reactivity of both Portland cement and clinker with treated sediment $\mathrm{L}$ at $650^{\circ} \mathrm{C}$. The cement-treated sediment additions showed a high calorific effect for only $8 \%$ by weight of treated sediment. Thus, this hydraulic reactivity weakened progressively by increasing the amount of sediment addition. In addition, a third peak was observed on the curve of sample with $16 \%$ and $33 \%$ of treated sediment which is may be related to the reaction of calcium aluminates phases and metakaolin. In the other hand, a large calorimetric effect for the clinker-treated sediment additions cause greater hydraulic reactivity due to the effect of the co-grinding of blended clinker and the presence of metakaolin (18).

Aouad et al. (7) achieved the rates of heat evolution of the Portland cement clinker synthesized by using up to $39 \%$ sediment and showed a similar 
hydration behavior to the commercial OPC. Thus, it was occurred early by the fact of the differences in the fineness, which was higher for the synthesized cement than for the OPC.

In conclusion to the hydration study we can associate the observed high calorimetric effect of samples containing oyster shell powder and sediment additions to additional hydraulic reactivity of additions due to the presence of metakaolin and gismondine from treated sediments and to the nascent form of $\mathrm{CaO}$ from heated shell powder identified in these samples. Likewise, the high finesses of particle size distribution of the treated materials increase also the reactivity of the samples due to the dissolution of a large area (24).

\subsection{Porosity, density and apparent permeability}

The results of the apparent porosity, bulk density and apparent gas permeability are shown in table 4 .

The values show that the apparent porosity was increased with the amount of the additions and the apparent density was slightly reduced. It is noted that the mortars with large addition quantities are more difficult to be pouring into the molds and caused the formation of more air bubbles. This result may be due to the sediment characteristics, they have a higher Blaine surface area than Portland cement (12).

The apparent permeability to the helium gas is measured on the sample after drying at $105^{\circ} \mathrm{C}$. The results for samples containing single sediment (OL or OM) show that the apparent permeability was increased according to the amount of the added addition. The additions OL650 and OM650 see their apparent permeability increased to $3.2410^{-15} \mathrm{~m}^{2}$

TABLE 4. Physical properties of hardened cylindrical mortars after 28 days cured in water

\begin{tabular}{lccc}
\hline Mortars & $\begin{array}{c}\text { Apparent density } \\
\left(\mathbf{K g} / \mathbf{m}^{3}\right)\end{array}$ & $\begin{array}{c}\text { Apparent } \\
\text { prosity (\%) }\end{array}$ & $\begin{array}{c}\text { Apparent } \\
\text { permeability } \\
\left(\mathbf{1 0}^{-15} \mathbf{~ m}^{\mathbf{2}}\right)\end{array}$ \\
\hline R & 2135.24 & 17.40 & 1.62 \\
R8OL650 & 2130.90 & 17.62 & 2.28 \\
R16OL650 & 2108.94 & 18.25 & 2.93 \\
R33OL650 & 2088.19 & 18.44 & 3.24 \\
R8OM650 & 2134.68 & 17.73 & 3.73 \\
R16OM650 & 2110.07 & 17.88 & 3.86 \\
R33OM650 & 2095.28 & 19.15 & 4.06 \\
R8OLM650 & 2132.89 & 18.06 & 1.05 \\
R16OLM650 & 2127.67 & 18.22 & 1.10 \\
R33OLM650 & 2110.47 & 18.89 & 1.26 \\
R8OLM850 & 2133.31 & 17.77 & 0.86 \\
R16OLM850 & 2125.91 & 18.36 & 0.90 \\
R33OLM850 & 2075.93 & 19.37 & 0.96 \\
\hline
\end{tabular}

and $4.0610^{-15} \mathrm{~m}^{2}$ respectively and it does not exceed $1.6210^{-15} \mathrm{~m}^{2}$ for reference mortar $\mathrm{R}$.

Furthermore, it was observed that mortars substituted by OLM650 and OLM850 additions, leads to a lower apparent permeability than those of the reference mortar $\mathrm{R}$. The measured values vary between $1.0510^{-15} \mathrm{~m}^{2}$ and $1.2610^{-15} \mathrm{~m}^{2}$ for OLM650 samples and between $0.8610^{-15} \mathrm{~m}^{2}$ and $0.9610^{-15} \mathrm{~m}^{2}$ for OLM850 samples. This reduction of the gas permeability could be explained by the presence of pores less connected within the structure while the apparent porosity is higher (13).

It is also important to note that the mortars substituted with large amounts of these additions have microcracks which occur on the walls of the samples. Some authors have found that the microstructure of cementitious materials may be damaged at a temperature above $60{ }^{\circ} \mathrm{C}$ because of the deterioration of ettringite or $\mathrm{CSH}(25,26)$. However, others found that the effect of temperature on the microstructure is low when the temperature is below $105^{\circ} \mathrm{C}(27)$.

\subsection{Compressive strength}

Figure 7 shows the compressive strength of different mortars cured for 28 days in water. The results show that the compressive strength of the reference mortar $\mathrm{R}$ is $60.3 \mathrm{MPa}$. The introduction of OS powder and sediment addition as a substitute of Portland cement CEM I 52.5 lead to a decrease of the mortar strength. The addition of the two sediments and OS powder treated both at $650{ }^{\circ} \mathrm{C}$ and $850^{\circ} \mathrm{C}$ decrease linearly the compressive strength of mortars. However, the addition $16 \%$ of OL650 or OM650 additions shows a drop of $45 \%$ of the compressive strength. Thus the treated additions have less performance than the Portland cement CEM I. The resistance class of different binders of the additions was determined according to EN 197-1 (28). Mortars R8OLM850, R16OLM850, R8OLM650 and R8OL650 have a high compressive strength than $52.5 \mathrm{MPa}$, which maintained these additions in the 52.5 Class. Mortars R8OM650, R16OLM650 and R33OLM850 are classified as 42.5 Class. A decrease in strength was observed for R16OL650, R33OL650 and R16OM650 mortars which are classified in 32.5 Class.

The increase of treated sediment ratio as a substitute for Portland cement CEM I lead to a linear decrease in strength of mortar (13). Dang et al. (13) have found that treated sediment $\mathrm{L}$ at $650{ }^{\circ} \mathrm{C}$ develop the compressive strength. It is attributed to the presence of clay and metakaolin in the sediment which participated in the cement hydration process and improves strength of the final hydrates. In addition, it was found that the substitution of OS as fine aggregate did not cause reduction in the compressive strength of concrete at age 28 days $(10,11)$. 


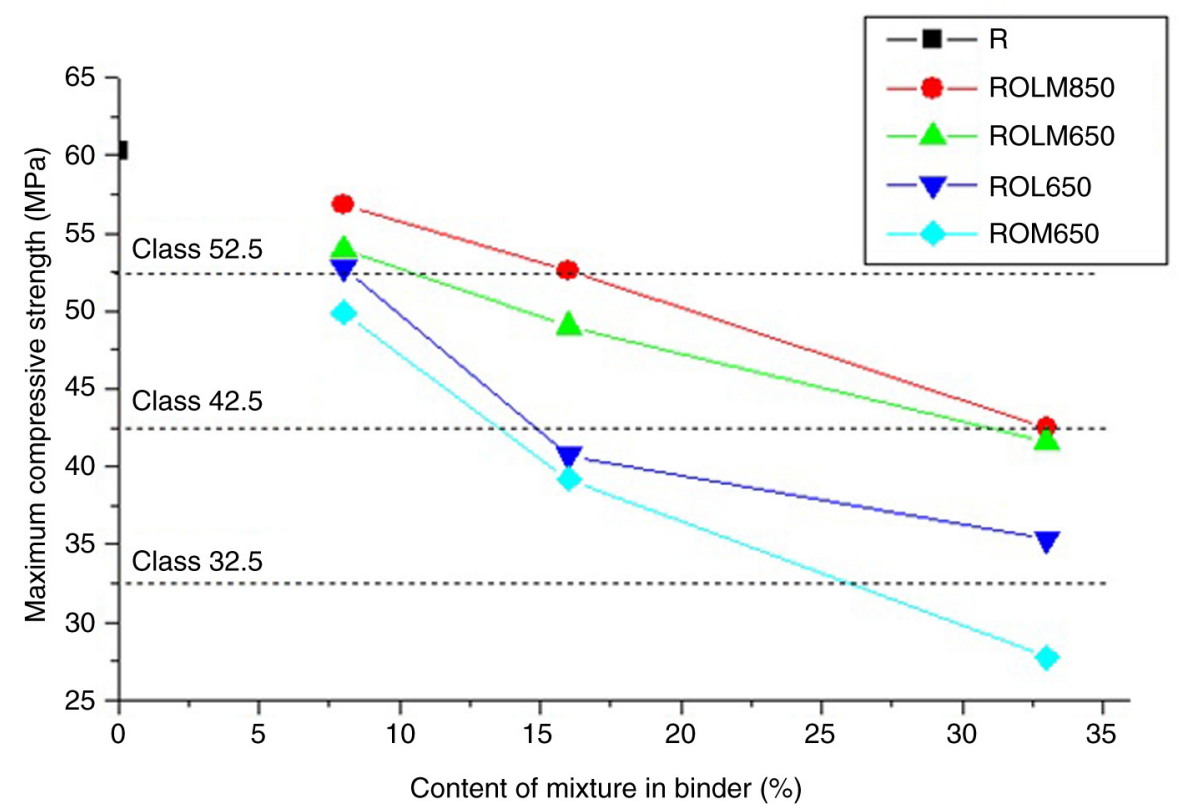

Figure 7. Compressive strength evolution at 28 days of cured mortars in water depending on the degree of substitution.

\subsection{Accelerated carbonation}

The carbonated thickness measurement was performed with the colored indicator of $\mathrm{pH}$ : phenolphthalein which reveals the color difference of the $\mathrm{CO}_{2}$ penetration depth into the test specimen. The results of the $\mathrm{CO}_{2}$ penetration depth in the studied samples are shown in Figure 8.

The results show that accelerated carbonation for 7 days a maximum of $2 \mathrm{~mm}$ of carbonated thicknesses on the test specimens containing 33\% of the OL650, OM650 and OLM650 additions. Furthermore, the $\mathrm{CO}_{2}$ penetration is based on the cement replacement rates. After 30 days, the carbonation effect is more significant. The addition amount was responsible of larger penetration thickness. Significant carbonation penetration values are obtained for blends containing 33\% of substituent. This result can be explained by the fact that the test specimens containing 33\% of the addition has a high porosity, which promoted the $\mathrm{CO}_{2}$ penetration. Some authors have observed that an addition of treated sediments beyond 30\% increase carbonation mortars (12). In other research, it's shown that the addition of OS has no apparent effect on carbonation of concrete. The carbonation depth increased with increasing carbonation ages (11).

\section{CONCLUSIONS}

This paper proposes the possibility of using the thermally activated sediment and oyster shell powder to replace a part of Portland cement CEM I 52.5 in order to reduce the impact of the cement industry on the environment by using natural waste.
Based on the different experimental tests, conclusions can be drawn:

- The studied sediments have very high water content and chloride and a large content of fine particles. They contain different minerals: calcite, quartz, illite and kaolinite. The oyster shell (OS) powder is composed essentially of calcium carbonate.

- The hydration of prepared additions shows a significant calorimetric effect on specific samples with 8 and $16 \%$ of additions. This demonstrates an optimum composition with good hydraulic reactivity in an addition mainly weakens on cement. A large calorimetric effect is caused by the hydraulic reactivity of additions due the presence of metakaolin, gismondine and the nascent $\mathrm{CaO}$, also due to the high fineness of particle size of treated sediment and OS powder.

- The apparent porosity increases with the addition of powder and OS sediments. This may be because the added materials cause the formation of air bubbles during the mixing operations at the fresh state.

- The apparent gas permeability increases moderately with the amount of added addition. However, the addition of an amount up to $33 \%$ of treated addition at $650^{\circ} \mathrm{C}$ or $850^{\circ} \mathrm{C}$ gives lower gas permeability than the control mortar. This implies that these additions are able to reduce the connectivity within the pores structure. A quick drying of mortars substituted with large amounts of these additions occur microcracks on the walls of the samples and can damage the microstructure of cementitious material. 


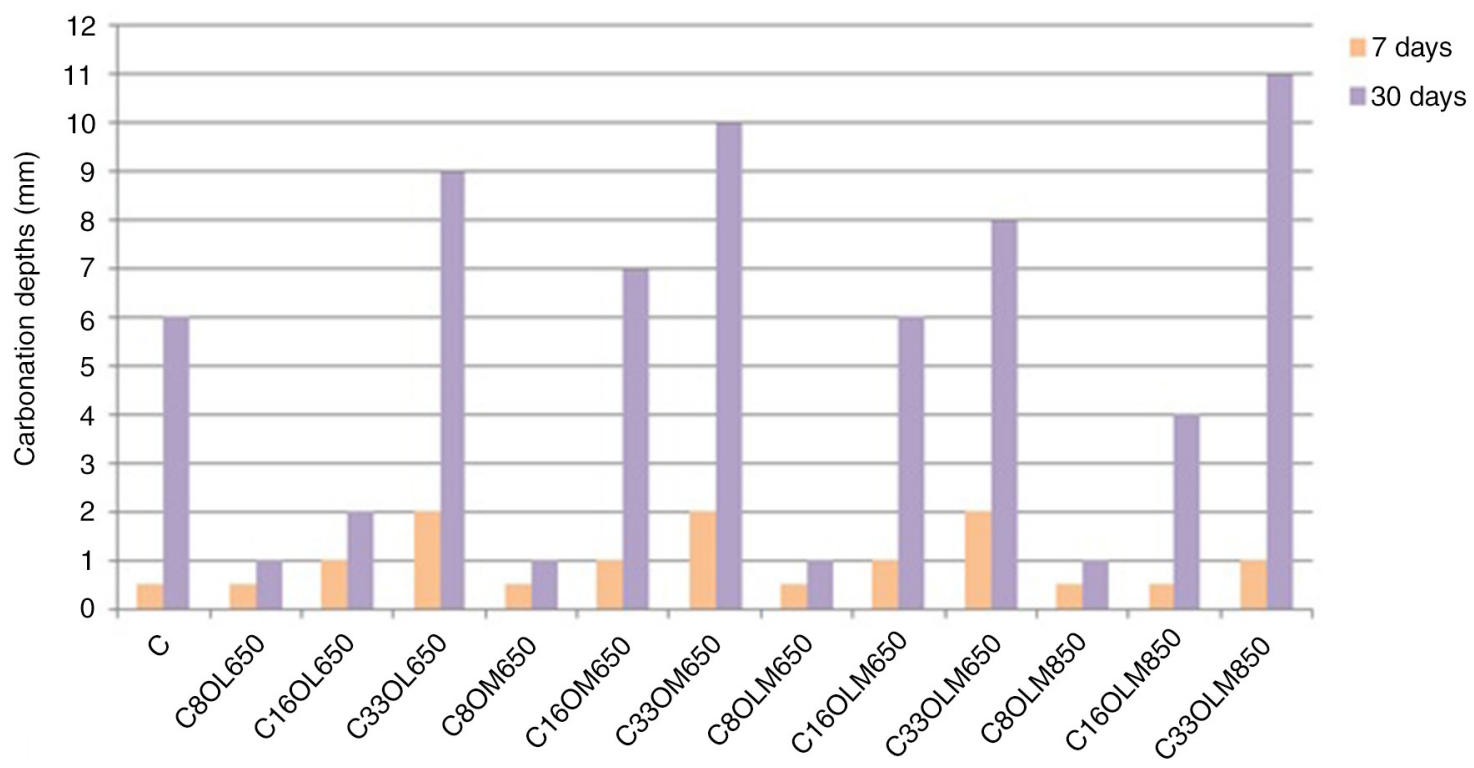

FIgURE 8. $\quad \mathrm{CO}_{2}$ penetration depth at 7 days and 30 days.

- For all sediments and OS powder calcined at both $650{ }^{\circ} \mathrm{C}$ and $850^{\circ} \mathrm{C}$, the compressive strength decrease with the rate of substitution. However, this drop is acceptable and remains interesting. According to EN 197-1 can be used up to $33 \%$ of OLM 850 addition or $16 \%$ of OLM650 addition to have 42.5 Class cement.

- The carbonation depth increase with increasing carbonation ages. After 30 days, it was significant with the addition content. Above than $16 \%$, the penetration of carbon dioxide is larger than that of the reference paste. This is due to the presence of a high porosity on the composite cement with $33 \%$ which promotes the penetration of the carbon dioxide.

The substitution of high quantities of marine waste in mortar is not only technically feasible, but it allows obtaining mortar with high hydraulic and mechanical performance. These natural wastes can be used as natural resources of materials for the blended cement production.

\section{ACKNOWLEDGEMENTS}

The authors would like to thank Huber Curient Volubilis Program for the financial support given by the grant $\mathrm{N}^{\circ} \mathrm{MA} / 10 / 236$ in the framework of a France-Morocco exchange 2010-2013.

\section{REFERENCES}

1. Lafhaj, Z.; Samara, M.; Boucard, L.; Agostini F.; Skoczylas, F. (2006) Polluted River Sediments: Characterization, Treatment and Valorization, Proceedings of the First Euro Mediterranean in Advances on Geomaterials and Structures, Hammamet, Tunisia.
2. Kribi, S.; Nzihou, A.; Sharrock, P.; Depelsenaire, G. (2005) Stabilization of Heavy Metals from Sediments Tailoring of Residue Properties, Proceedings of the Third International Conference on Remediation of Contaminated Sediments, Battelle Press, New Orleans, Louisiana, USA, January, ISBN: 1-57477-150-7.

3. Agostini, F.; Skoczylas, F.; Lafhaj, Z. (2007) About a possible valorisation in cementitious materials of polluted sediments after treatment. Cem. Concr. Compos. 29 [4], 270-278. http:// dx.doi.org/10.1016/j.cemconcomp.2006.11.012.

4. Lafhaj, Z.; Samara, M.; Agostini, F.; Boucard, L.; Skoczylas F; Depelsenaire G. (2008) Polluted river sediments from the North region of France: Treatment with Novosol ${ }^{\mathbb{Q}}$ process and valorization in clay bricks. Constr. Build. Mater. 22 [5], 755-762. http://dx.doi.org/10.1016/j.conbuildmat. 2007.01.023.

5. Kamali, S.; Bernard, F.; Abriak, NE.; Degrugilliers, P. (2008) Marine dredged sediments as new materials resource for road construction. Waste Management. 28 [5], 919-928. http:// dx.doi.org/10.1016/j.wasman.2007.03.027.

6. Agostini, F.; Davy, C.A.; Skoczylas, F.; Dubois, Th. (2010) Effect of microstructure and curing conditions upon the performance of a mortar added with Treated Sediment Aggregates (TSA). Cem. Concr. Res. 40 [11], 1609-1619. http://dx.doi.org/10.1016/j.cemconres.2010.07.003.

7. Aouad, G.; Laboudigue, A.; Gineys, N.; Abriak, N.E. (2012) Dredged sediments used as novel supply of raw material to produce Portland cement clinker. Cem. Concr. Compos. 34 [6], 788-793. http://dx.doi.org/10.1016/j.cemconcomp. 2012.02.008

8. Yoon, GL.; Kim, BT.; Kim, BO.; Han, SH. (2003) Chemicalmechanical characteristics of crushed oyster-shell. Waste Manage. 23 [9], 825-834. http://dx.doi.org/10.1016/S0956053X(02)00159-9.

9. Wang, HY.; Kuo, WT.; Lin CC.; Chen PY. (2013) Study of the material properties of fly ash added to oyster cement mortar. Constr. Build. Mater. 41, 532-537. http://dx.doi. org/10.1016/j.conbuildmat.2012.11.021.

10. Yang, EI.; Yi ST.; Leem, YM. (2005) Effect of oyster shell substituted for fine aggregate on concrete characteristics: Part I. Fundamental properties. Cem. Concr. Res. 35 [11], 2175-2182. http://dx.doi.org/10.1016/j.cemconres.2005.03.016.

11. Yang, EI.; Kim, MY.; Park, HG.; Yi S.T. (2010) Effect of partial replacement of sand with dry oyster shell on the long-term performance of concrete. Constr. Build. Mater. 24 [5], 758-765. http://dx.doi.org/10.1016/j.conbuildmat.2009.10.032 
12. Dang, T.A. (2011) Valorisation durable des sédiments marins Bretons comme matériaux de construction, Thèse de Doctorat-INSA Rennes.

13. Dang, T.A.; Kamali, S.; Prince, W.A. (2013) Design of new blended cement based on marine dredged sediment. Constr. Build. Mater. 41, 602-611. http://dx.doi.org/10.1016/j. conbuildmat.2012.11.088.

14. EN 196-1, (2006) European standard, methods of testing cement-Part 1: Determination of strength. NF EN 196-1.

15. AFREM Group, «Les résultats des essais croises AFREM pour la determination de la masse volumique apparente et de la porosité accessible à l'eau des bétons ").

16. Care, S.; Derkx, F. (2011) Determination of relevant parameters influencing gas permeability of mortars. Constr. Build. Mater. 25 [3], 1248-1256. http://dx.doi.org/10.1016/j. conbuildmat.2010.09.028.

17. Hamami, A.A.; Turcry, Ph.; Aït-Mokhtar, A. (2012) Influence of mix proportions on microstructure and gas permeability of cement pastes and mortars. Cem. Concr. Res. 42 [2], 490-498. http://dx.doi.org/10.1016/j.cemconres.2011. 11.019.

18. Lagier, F.; E. Kurtis, K. (2007) Influence of Portland cement composition on early age reactions with metakaolin. Cem. Concr. Res. 37, [10] 1411-1417. http://dx.doi.org/10.1016/j. cemconres.2007.07.002.

19. Rahhal, V.; Cabrera, O.; Talero, R.; Delgado, A. (2007) Calorimetry of portland cement with silica fume and gypsum additions. J. Therm. Anal. Calor. 87, 331-336. http://dx.doi. org/10.1007/s10973-005-7324-1.

20. Rahhal, V.; Talero, R. (2009) Calorimetry of Portland cement with silica fume, diatomite and quartz additions. Constr. Build. Mater. 23 [11], 3367-3374. http://dx.doi.org/10.1016/j. conbuildmat.2009.06.003.

21. Rahhal, V.; Talero, R. (2008) Calorimetry of Portland cement with metakaolins, quartz and gypsum additions. J. Therm.
Anal. Calor. 91, 825-834. http://dx.doi.org/10.1007/s10973006-8250-6.

22. Christensen, A.N.; Jensen, T.R.; Hanson, J.C. (2004) Formation of ettringite, $\mathrm{Ca}_{6} \mathrm{Al}_{2}\left(\mathrm{SO}_{4}\right)_{3}(\mathrm{OH})_{12} \cdot 26 \mathrm{H}_{2} \mathrm{O}$, AFt, and monosulfate, $\mathrm{Ca}_{4} \mathrm{Al}_{2} \mathrm{O}_{6}\left(\mathrm{SO}_{4}\right) .14 \mathrm{H}_{2} \mathrm{O}$, AFm-14, in hydrothermal hydration of Portland cement and of calcium aluminum oxide-calcium sulfate dihydrate mixtures studied by in situ synchrotron X-ray powder diffraction. Journal of Solid State Chemistry. 177 [6], 1944-1951. http://dx.doi. org/10.1016/j.jssc.2003.12.030.

23. Ez-zaki, H.; Diouri, A.; Kamali, B.S.; Dang, T.A.; Sassi, O.; Bernard, F. (2013) Properties and hydration behavior of blended clinker and Portland-sediment cement pastes. Chemistry and Materials Research 5, 121-127.

24. Bentz, D.P.; Haecker, C.J. (1999) An argument for using coarse cements in high-performance concretes. Cem. Concr. Res. 29 [4], 615-618. http://dx.doi.org/10.1016/S0008-8846 (98)00201-4.

25. Gallé, C. (2001) Effect of drying on cement-based materials pore structure as identified by mercury intrusion porosimetry. A comparative study between oven-, vacuum-, and freeze-drying. Cem. Concr. Res. 31 [10], 1467-1477. http:// dx.doi.org/10.1016/S0008-8846(01)00594-4.

26. Sanjuán, M.A.; Muñoz-Martialay R. (1996) Oven-drying as a preconditioning method for air permeability test on concrete, Mater. Lett. 27 [4-5], 263-268. http://dx.doi.org/ 10.1016/0167-577X(95)00283-9.

27. Noumowé, A.N.; Clastres, P.; Debicki, G.; Costaz, J-L. (1996) Thermal stresses and water vapour pressure of High Performance Concrete at High Temperature. 4th International Symposium on Utilization of High-strength/ High-performance concrete, Paris, May.

28. EN 197-1, (2001) European standard, cement-Part 1: Composition, specifications, and conformity criteria. NF EN 197-1. 